\title{
Faktor-Faktor Penentu Kualitas Penyerapan Anggaran Dana Desa
}

\author{
Kadek Krisna Desiantini ${ }^{*}$, Made Aristia Prayudi²
}

1,2Universitas Pendidikan Ganesha, Singaraja - Indonesia

\section{A R T I C L E I N F O}

Article history:

Received July, 112020

Received in revised form June, 102021

Accepted June, 102021

Available online June, 28 2021

\begin{tabular}{l}
\hline Kata Kunci: \\
Karakteristik \\
kepemimpinan, kualitas \\
perencanaan anggaran, \\
kualitas penyerapan \\
anggaran, tingkat \\
partisipasi masyarakat. \\
Keywords: \\
Leadership characteristics, \\
level of community \\
participation, quality of \\
budget absorption, quality \\
of budget planning.
\end{tabular}

\begin{abstract}
A B S T R A K
Penelitian ini bertujuan untuk mengetahui pengaruh kualitas perencanaan anggaran, tingkat partisipasi masyarakat, dan karakteristik kepemimpinan terhadap kualitas penyerapan anggaran dana desa. Penelitian ini dilakukan pada 30 desa yang ada di Kabupaten Buleleng dengan jumlah responden sebanyak 150 orang. Jenis penelitian ini menggunakan metode kuantitatif dengan menggunakan data primer dan sekunder. Teknik pengambilan sampel yang digunakan yaitu purposive sampling. Data diolah menggunakan uji analisis regresi linear berganda. Hasil penelitian menunjukan bahwa kualitas kualitas perencanaan anggaran, tingkat partisipasi masyarakat, dan karakteristik kepemimpinan berpengaruh secara positif dan signifikan terhadap kualitas penyerapan anggaran dana desa.
\end{abstract}

\section{A B S T R A C T}

This study aims to determine the effect of the quality of budget planning, the level of community participation, and leadership characteristics on the quality of village fund budget absorption. This research was conducted in 30 villages in Buleleng Regency with 150 respondents. This type of research uses quantitative methods using primary and secondary data. The sampling technique used is purposive sampling. The data is processed using multiple linear regression analysis test. The results showed that the quality of budget planning, the level of community participation, and leadership characteristics positively and significantly affected the quality of village budget absorption.

\footnotetext{
* Corresponding author.

E-mail : krisnadesiantini34@gmail.com (made.aristia.prayudi@undiksha.ac.id)
} 


\section{Pendahuluan}

Sebagai ujung tombak pembangunan daerah, pemerintah desa berperan dan bertanggung jawab untuk mengelola potensi desa yang dimiliki demi meningkatkan perekonomian, dan meningkatkan kesejahteraan masyarakat desa, terlebih lagi desa merupakan organisasi sektor publik yang berhadapan langsung dengan kehidupan masyarakat dalam berbagai kepentingan dan kebutuhan yang berbeda-beda, peranan pemerintah desa secara strategis yaitu memiliki tugas di bidang pelayanan kepada masyarakat. Bentuk transfer dana dari pemerintah pusat dalam menunjang pembangunan di desa adalah Dana Desa (DD). Dana Desa merupakan dana yang bersumber dari Anggaran Pendapatan dan Belanja Negara (APBN) yang ditransfer kepada masing-masing desa melalui Anggaran Pendapatan dan Belanjar Daerah (APBD) Kabupaten atau Kota yang diperuntukan membiayai prioritas kegiatan masyarakat di bidang pembangunan desa dan pemberdayaan masyarakat.

Dana desa tersebut kemudian dialokasikan oleh pemerintah melalui mekanisme transfer kepada masing-masing kabupaten atau kota yang dihitung berdasarkan jumlah desa, dan pengalokasiannya dilakukan dengan memperhatikan kriteria jumlah penduduk, luas wilayah, angka kemiskinan dan tingkat kesulitan geografis di desa. Permasalahan yang sering terjadi dalam anggaran pemerintah adalah penyerapan anggaran yang rendah di awal tahun dan menumpuk di akhir tahun sehingga menyebabkan penyerapan anggaran yang tidak merata (Suwarni, 2018). Anggaran adalah pernyataan mengenai estimasi kinerja pemerintah yang hendak dicapai selama periode waktu tertentu yang dinyatakan dalam ukuran finansial dan digunakan untuk menjalankan roda pemerintahan. Menurut (Anfujatin, 2016) salah satu indikator yang menunjukkan keberhasilan program atau kebijakan pemerintah yang telah dilakukan yaitu penyerapan anggaran. Adapun penyerapan anggaran yang dibahas dalam penelitian ini adalah keberhasilan perangkat desa dalam merealisasi anggaran dana desa sesuai dengan program yang sudah ditetapkan dalam APBDes.

Penyerapan anggaran yang rendah merupakan masalah yang sering terjadi atau bisa dibilang masalah klasik di Indonesia, karena hal ini terus terjadi setiap tahunnya. Dalam UU. No. 9 Tahun 2015 tentang Pemerintah Daerah dan Undan-undang Nomor 33 Tahun 2004 Tentang Perimbangan antara Pemerintah Pusat dan Pemerintah Daerah yang digunakan sebagai dasar dalam pelaksanaan otonomi daerah telah dituangkan proses penyusunan anggaran. Adanya Undang-Undang tersebut, mengandung makna pemerintah pusat memberi wewenang kepada pemerintah daerah dengan memberi bantuan berupa dana desa. Salah satu permasalahan dalam anggaran dana desa di Kabupaten Buleleng Provinsi Bali adalah serapan dana desa pada sejumlah desa yang masih rendah atau capaian outputnya berada di bawah 50\%. Kejadian ini mengakibatkan terjadinya penundaan transfer Dana Alokasi Umum (DAU) di beberapa desa di buleleng. (Sumber : Nusa Bali.com). Dana desa yang diterima Provinsi Bali pada tahun 2019 yaitu sebesar Rp. 630.189.586.000. Dimana Buleleng merupakan kabupaten penerima dana desa terbesar di Bali yaitu sebesar Rp. 124.026.738.000. Kabupaten Buleleng terdiri dari 9 kecamatan dengan jumlah desa sebanyak 129 desa. Dana desa yang sangat besar ini mulai menjadi kekhawatiran bagi pemerintah terutama mengenai kesiapan desa dalam mengelola dana desa yang dialokasikan.

Pada penelitian ini terdapat beberapa faktor yang diprediksi berpengaruh terhadap kualitas penyerapan anggaran dana desa, yang pertama adalah kualitas perencanaan anggaran. Perencanaan secara umum diartikan sebagai suatu tindakan yang dilakukan untuk mencapai hasil yang lebih baik di periode yang akan datang dengan memperhatikan keadaan saat ini maupun sebelumnya. Dalam penyusunan anggaran, ajuan yang diusulkan oleh pihak eksekutif mempunyai beban mengutamakan kepentingan eksekutif (Smith \& Bertozzi., 1998). Pelaksana akan mengajukan anggaran yang akan dapat memperbesar agencynya, baik dari segi finansial maupun nonfinansial. Menurut Arif dan Halim, 2013 dalam (Iqbal, 2018) menyatakan bahwa semakin maksimal perencanaan anggaran maka seluruh program kerja dalam satu periode anggaran akan berjalan dengan lancar, sehingga mampu memcapai target penyerapan anggaran. Namun sebaliknya apabila perencanaan kegiatan kurang maksimal, akan berimplikasi pada pelaksanaan kegiatan yang tidak sesuai dengan perencanaannya. Perencanaan anggaran yang tidak dipersiapkan dengan matang akan menimbulkan hambatan, sehingga harus direvisi lagi bahkan tidak dapat direalisasi sama sekali.

Perencanaan anggaran juga memiliki peranan penting dan memberi kontribusi bagi penyerapan anggaran pemerintah daerah. Dalam penelitian (Suwarni, 2018), faktor-faktor yang mempengaruhi keterlambatan penyerapan anggaran di Kota Surabaya, adalah lemahnya perencanaan anggaran. Kemudian hasil penelitian Setyawan (2016) tentang analisis keterlambatan penyerapan anggaran belanja satuan kerja kementrian/lembaga di wilayah pembayaran KPPN Bojonegoro tahun anggaran 2018 menunjukan bahwa perencanaan anggaran merupakan faktor yang paling dominan dalam keterlambatan penyerapan anggaran belanja. Sejalan dengan (Widianingrum, Kustono, \& Suryaningsih, 2017) dan (Iqbal, 2018) menyatakan bahwa faktor perencanaan anggaran berpengaruh terhadap penyerapan anggaran. 
Penelitian yang dilakukan oleh (Zarinah, Darwanis, \& Abdullah, 2016) dan Dwiyana (2017) menyatakan bahwa faktor perencanaan anggaran berpengaruh terhadap penyerapan anggaran. Tetapi berbeda dengan penelitian yang dilakukan oleh (Rifai, Inapty, \& Pancawati M., 2016) dan Halim (2018) yang menyatakan bahwa perencanaan anggaran tidak berpengaruh terhadap penyerapan angggaran. Berdasarkan uraian diatas, dapat dirumuskan hipotesis pertama sebagai berikut:

\section{H: Kualitas Perencanaan Anggaran Berpengaruh Positif Terhadap Kualitas Penyerapan Anggaran Dana Desa.}

Faktor kedua yang diduga mempengaruhi penyerapan anggaran adalah Partisipasi masyarakat. Partisipasi Masyarakat yaitu keikut sertaan masyarakat dalam proses mengindentifikasikan masalah dan potensi yang dimiliki desa, serta memberi jalan keluar untuk menyelesaikan masalah. Dana Desa harus dikelola dengan baik agar dana yang diberikan pemerintah memang benar-benar dapat dirasakan manfaatnya bagi masyarakat di masing-masing desa. Oleh karena itu, salah satu faktor yang mempengaruhi peyerapan anggaran dana desa adalah Partisipasi Masyarakat. Partisipasi masyarakat dapat membantu dan berperan serta dalam berbagai kegiatan desa, seperti perencanaan, penetapan kebijakan anggaran dan pembangunan desa. (Gilardi, 2001) dan(Strom, 2000), melihat hubungan keagenan sebagai relasi pendelegasian wewenang (chains of delegation), yaitu pendelegasian dari masyarakat kepada wakil rakyat di pemerintahan, dari parlemen kepada pemerintah, dari pemerintah sebagai satu kesatuan kepada seorang menteri, dan juga dari pemerintah kepada birokrasi. Dalam teori agensi masyarakat berperan sebagai pihal principal atau pemberi kepercayaan terhadap proses pelaksanaan pembangunan dan pemerintahan desa. Hubungan teori agensi dalam penelitian ini adalah kualitas penyerapan anggaran yang baik ketika partisipasi masyarakat juga tinggi.

Dalam penelitian (Julianto \& Dewi, 2019) yang sejalan dengan (Umaira \& Adnan, 2019) mengungkapkan bahwa partispasi masyarakat berpengaruh secara positif dan signifikan terhadap keberhasilan pengelolaan dana desa. Hal ini juga sesuai dengan penelitian yang dilakukan oleh Wiguna (2017) menunjukan bahwa partisipasi penyusunan anggaran berpengaruh positif terhadap kinerja aparat pemerintah. Sejalan dengan penelitian yang dilakukan oleh Sahputra (2018) yang menyatakan bahwa penganggaran partisipastif berpengaruh terhadap slack anggaran pada SKPK di Pemerintah Aceh. Berdasarkan uraian diatas, dapat dirumuskan hipotesis kedua sebagai berikut:

\section{H$^{2}$ : Tigkat Partisipasi Masyarakat Berpengaruh Posisitf Terhadap Kualitas Penyerapan Anggaran Dana Desa}

Faktor berikutnya yang diduga mempengaruhi penyerapan anggaran dana desa adalah Karakteristik Kepemimpinan. Karakter merupakan salah satu kunci utama kesuksesan seorang pemimpin. Sukses atau tidaknya seorang pemimpin sangat di pengaruhi oleh karakter yang dimilikinya terlebih lagi seorang pemimpin merupakan teladan bagi orang lain, terutama bagi bawahannya. Pemimpin yang baik adalah seorang pemimpin yang memiliki karakter berpendirian teguh, jujur, integritas, proaktif, fleksible, komunikatif, berfikiran terbuka, cerdas, percaya diri, antusias, teratur, evaluatif, penuh penghargaan, dan menginspirasi. (Kartono \& Kartini, 2014) menjelaskan bahwa kepemimpinan ialah kemampuan seseorang untuk mempengaruhi orang lain atau sekelompok orang dalam mencapai target ditetapkan. Dalam teori agensi aparatur desa berperan selaku agen, yang diberikan tanggung jawab oleh pemerintah pusat dan diberikan amanah oleh masyarakat untuk mengelola keuangan desa. Kepala desa selaku pemimpin dalam pemerintahan desa, mempunyai peranan sebagai penanggung jawab pengelolaan keuangan desa dan mewakili pemerintah desa dalam kepemilikan kekayaan desa (Bastian, 2015). Sebagai pihak agen kepemimpinan kepala desa berperan dalam memotivasi bawahannya dalam menyelesaikan tugas tidak terkecuali dalam pengelolaan dana desa.

Dalam penelitian Nor, (2007) kesuksesan seseorang dalam mengelola organisasi tidak terlepas dari faktor kepemimpinan dan sikap bawahan dalam melaksanakan tugas untuk mencapai tujuan organisasi. Decoster dan Fertakis, (1968) dalam Nor, (2007) mendefinisikan kepemimpinan yang efektif harus memberikan pengarahan yang positif terhadap usaha-usaha dalam mencapai tujuan organisasi. Hal ini juga searah dengan penelitian yang dilakukan oleh Bagus et al, (2013), Ratu, (2017), serta (Dewi \& Gayatri, 2019) yang menyimpulkan bahwa kepemimpinan berpengaruh secara positif terhadap akuntabilitas pengelolaan dana desa. Berdasarkan pemaparan diatas, dirumuskan hipotesis ketiga sebagai berikut:

\section{H$^{3}$ : Karakteristik Kepemimpinan Berpengaruh Posistif Terhadap Kualitas Penyerapan Anggaran Dana Desa}

Ketidak konsistenan hasil penelitian di atas, sangat menarik untuk mengkaji lebih jauh hubungan keagenan eksekutif dan legislatif tersebut tersebut dalam proses anggaran pada pemerintah desa. Maka dilakukan penelitian yang berjudul "Pengaruh Kualitas Perencanaan Anggaran, Tingkat Partisipasi Masyarakat, dan Karakteritik Kepemimpinan Terhadap Kualitas Penyerapan Anggaran Dana Desa”. Selain 
itu, hal lain yang menarik peneliti untuk melakukan penelitian di di Kabupaten Buleleng yaitu karena Kabupaten Buleleng merupakan penerima dana desa terbesar di Provinsi Bali pada tahun 2019. Terdapat 30 desa di Kabupaten Buleleng yang mengalami keterlambatan dalam penyetoran Laporan Pertanggungjawaban (LPJ) Dana Desa Tahap II, dan terdapat beberapa desa di Buleleng yang penyerapan anggaran dana desa nya rendah atau di bawah $50 \%$.

Berdasarkan mepaparan yang dijelaskan diatas, tujuan dari penelitian ini yaitu untuk menguji pengaruh Kualitas Perencanaan Anggaran, Tingkat Partisipasi Masyarakat, dan Karakteristik Kepemimpinan terhadap Kualitas Penyerapan Anggaran Dana Desa.

\section{Metode}

Penelitian ini dilakukan pada desa-desa di kabupaten Buleleng yang mengalami keterlambatan dalam penyetoran laporan pertanggungjawaban dana desa tahap I dan II dan penyerapan anggaran dana desa dibawah 50\%. Rancangan penelitian yang digunakan adalah kuantitatif. Sumber data dari penelitian ini didapat dari perangkat desa desa di Kabupaten Buleleng dengan menggunakan daftar pertanyaan kuisioner. Untuk mengolah data, peneliti menggunakan bantuan program SPSS (Statistcal Package for Social Science). Dalam penelitian ini adapun populasi yang digunakan adalah desa-desa yang ada di Kabupaten Buleleng yang mengalami keterlambatan penyetoran LPJ Dana desa tahun 2019. Teknik penentuan sampel yang digunakan adalah purposive sampling, yaitu teknik pengambilan sampel dengan beberapa pertimbangan tertentu. Kriteria pemilihan sampel dalam penelitian ini adalah desa-desa di Kabupaten Buleleng yang penyerapan anggaran dana desa nya rendah, Desa-desa yang terlambat dalam penyetoran Laporan Pertanggung Jawaban (LPJ) Dana desa tahap I dan II dan Desa yang Kepala desa nya sudah menjabat lebih dari 1 tahun Jumlah desa yang digunakan yaitu sebanyak 30 desa. Dengan jumlah responden sebanyak 150 responden, yang terdiri dari perangkat desa yang memegang jabatan sebagai Kepala desa dan Tim Pelaksana Teknis Pengelola Keuangan Desa (PTPKD) yang terdiri dari : Sekretaris Desa, Kepala Seksi dan Bendahara desa, sesuai dengan Permendagri No. 113 Tahun 2014 tentang Pengelolaan Keuangan Desa, serta telah menjabat pada bagian tersebut minimal selama 2 tahun. Data yang diperoleh dari penyebaran kuisioner kemudian akan diolah menggunakan uji statistik sebagai berikut : (1) Analisis Statistik Deskriptif (2) Uji Kualitas data yang terdiri dari Uji Validitas dan Uji Reliabilitas, (3) Uji Asumsi Klasik yang terdiri dari Uji Normalitas, Uji Multikoleniaritas, dan Uji Heterokedastisitas, (4) Uji Hipotesis yang terdiri dari Uji Regresi Linear Berganda, Uji F, Uji Koefisien Determinasi (Adjust R²) dan Uji T.

\section{Hasil dan Pembahasan}

Berdasarkan hasil uji Analisis Uji Statistik deskriptif, diperoleh 4 (empat) deskripsi umum hasil penelitian sebagai berikut : (1) Data variabel kualitas perencanaan anggaran yang diperoleh dari 150 responden memiliki nilai (minimum) sebesar 14, nilai tertinggi (maximum) sebesar 25 dengan nilai ratarata (mean) sebesar 20,98 dan Standar deviasi sebesar 2,375. Standar deviasi lebih kecil dari skor ratarata, menunjukan bahwa kualitas perencanaan anggaran sebaran skornya semakin dekat dari skor rataratanya, yang mengindikasikan respon terhadap kualitas perencanaan anggaran tidak bervariasi. (2) Data variabel tingkat partisipasi masyarakat yang diperoleh dari 150 responden memiliki nilai (minimum) sebesar 15, nilai tertinggi (maximum) sebesar 30 dengan nilai rata-rata (mean) sebesar 26,64 dan Standar deviasi sebesar 3,917. Standar deviasi lebih kecil dari skor rata-rata, menunjukan bahwa tingkat partisipasi masyarakat sebaran skornya semakin dekat dari skor rata-ratanya, yang mengindikasikan respon terhadap tingkat partisipasi masyarakat tidak bervariasi. (3) Data variabel karakteristik kepemimpinan yang diperoleh dari 150 responden responden memiliki nilai (minimum) sebesar 26, nilai tertinggi (maximum) sebesar 45 dengan nilai rata-rata (mean) sebesar 36,42 dan Standar deviasi sebesar 3,753. Standar deviasi lebih kecil dari skor rata-rata, menunjukan bahwa karakteristik kepemimpinan sebaran skornya semakin dekat dari skor rata-ratanya, yang mengindikasikan respon terhadap karakteristik kepemimpinan tidak bervariasi. (4) Data variabel kualitas penyerapan anggaran yang diperoleh dari 150 responden responden memiliki nilai (minimum) sebesar 10, nilai tertinggi (maximum) sebesar 20 dengan nilai rata-rata (mean) sebesar 15,88 dan Standar deviasi sebesar 2,327. Standar deviasi lebih kecil dari skor rata-rata, menunjukan bahwa kualitas penyerapan anggaran sebaran skornya semakin dekat dari skor rata-ratanya, yang mengindikasikan respon terhadap kualitas penyerapan anggaran tidak bervariasi. 
Berdasarkan hasil pengujian validitas diperoleh bahwa koefisien korelasi product moment tiap butir instrumen lebih besar dari syarat minimum yaitu 0,1603, sehingga setiap item pertanyaan kuisioner dinyatakan valid. Berdasarkan hasil pengujian reliabilitas Dapat dilihat bahwa setiap nilai Cronbanch Alpha lebih besar dari syarat minimum yaitu 0,60,(Sugiyono, 2008). Sehingga setiap pertanyaan dalam kuisioner dinyatakan reliabel.

Berdasarkan hasil uji normalitas diperoleh bahwa nilai kolmogrov smirnov sebesar 0.966 dengan nilai signifikansi atau Asymp. Sig (2-tailed) sebesar 0,308 > 0,05, (Gozali, 2007). Artinya, nilai residual telah berdistribusi normal. Uji Multikolinearitas bertujuan untuk menguji apakah pada model regresi ditemukan adanya korelasi antar variabel independen. Dalam penelitian ini menggunakan Nilai Tolerance dan Variance Inflation Factor (VIF) untuk mendeteksi adanya permasalahan multikolinearitas. Berdasarkan hasil uji multikoleniaritas diketahui bahwa semua variabel bebas pada penelitian ini memiliki nilai VIF lebih kecil dari pada 10 dan nilai tolerance lebih besar dari 0,10, variabel X1 dengan nilai tolerance 0,826 dan VIF sebesar 1,211, variabel X2 dengan nilai tolerance 0,737 dan VIF sebesar 1,357, variabel X3 dengan nilai tolerance 0,876 dan VIF sebesar 1,142, sehingga dapat ditarik kesimpulan bahwa pada variabel bebas tidak terjadi multikolinearitas. Homokedastisitas yaitu jika variance dari residual satu pengamatan ke pengamatan lainnya tetap atau nilai signifikansinya $>0,05$, sedangkan variance yang berbeda atau nilai signifikansinya $<0,05$ disebut heteroskedastisitas. Hasil uji heterokedastisitas pada penelitian ini terdapat pada tabel 1 berikut.

Tabel 1. Hasil Uji Heterokedastisitas

\begin{tabular}{|c|c|c|c|c|c|c|}
\hline \multicolumn{7}{|c|}{ Coefficients $^{a}$} \\
\hline \multicolumn{2}{|c|}{ Model } & \multicolumn{2}{|c|}{$\begin{array}{c}\text { Unstandardized } \\
\text { Coefficients }\end{array}$} & \multirow{2}{*}{$\begin{array}{c}\begin{array}{c}\text { Standardized } \\
\text { Coefficients }\end{array} \\
\text { Beta }\end{array}$} & \multirow[t]{2}{*}{$\mathrm{T}$} & \multirow[t]{2}{*}{ Sig. } \\
\hline & & $\mathrm{B}$ & Std. Error & & & \\
\hline \multirow[t]{4}{*}{1} & (Constant) & -.617 & 1.054 & & -.585 & .559 \\
\hline & $\mathrm{X} 1$ & .052 & .040 & .118 & 1.316 & .190 \\
\hline & $\mathrm{X} 2$ & -.040 & .025 & -.149 & -1.574 & .118 \\
\hline & X3 & .048 & .024 & .171 & 1.969 & .051 \\
\hline
\end{tabular}

Sumber : Data Diolah, 2020

Berdasarkan tabel diatas, diperoleh bahwa nilai signifikan masing-masing variabel bebas yaitu diatas 0,05, jadi tidak terjadi adanya heterokedastisitas.

Model regresi pada penelitian ini adalah menguji variabel kualitas perencanaan anggaran $\left(\mathrm{X}_{1}\right)$, Tingkat partisipasi masyarakat $\left(\mathrm{X}_{2}\right)$, Karakteristik kepemimpinan $\left(\mathrm{X}_{3}\right)$, dan Kualitas Penyerapan Anggaran (Y). Berikut disajikan hasil uji regresi linear berganda pada tabel 2 :

Tabel 2. Hasil Uji Regresi Linear Berganda

\begin{tabular}{|c|c|c|c|c|c|c|}
\hline \multicolumn{7}{|c|}{ Coefficients $^{a}$} \\
\hline & \multirow[t]{2}{*}{ Model } & \multicolumn{2}{|c|}{$\begin{array}{l}\text { Unstandardized } \\
\text { Coefficients }\end{array}$} & \multirow{2}{*}{$\begin{array}{c}\begin{array}{c}\text { Standardized } \\
\text { Coefficients }\end{array} \\
\text { Beta } \\
\end{array}$} & \multirow[t]{2}{*}{$t$} & \multirow[t]{2}{*}{ Sig. } \\
\hline & & $B$ & Std. Error & & & \\
\hline \multirow[t]{4}{*}{1} & (Constant) & -2.343 & 1.659 & & -1.412 & .160 \\
\hline & $\mathrm{X} 1$ & .191 & .062 & .195 & 3.077 & .002 \\
\hline & $\mathrm{X} 2$ & .226 & .040 & .380 & 5.650 & .000 \\
\hline & X3 & .238 & .038 & .383 & 6.215 & .000 \\
\hline
\end{tabular}

Sumber : Data Diolah, 2020

Berdasarkan hasil uji regresi linear berganda pada tabel 4 . Untuk variabel $\mathrm{X}_{1}$ diperoleh nilai signifikan 0,002 kurang dari 0,05, variabel $\mathrm{X}_{2}$ dengan signifikansi 0,000<0,05, dan variabel $\mathrm{X}_{3}$ dengan nilai signifikansi $0,000<0,05$. Jadi diperoleh hasil persamaan regresi berikut : Y = $2,343+0,191 X_{1}+0,226 X_{2}+0,238 X_{3}+1,659$. (1) Konstanta sebesar $-2,343$ menyatakan bahwa nilai variabel independen Kualitas Perencanaan Anggaran (X1), Tingkat Partisipasi Masyarakat (X2) dan Karakteristik 
Kepemimpinan (X3) sama dengan 0 (nol), maka variabel dependen (Y) Kualitas Penyerapan Anggaran adalah sebesar -2,343. (2) Koefisien regresi X1 sebesar 0,191 menunjukan bahwa terdapat pengaruh positif antara variabel kualitas perencanaan anggaran (X1) dengan variabel Kualitas penyerapan anggaran (Y) sebesar 0,191. Hal ini menandakan bahwa jika variabel bebas kualitas perencanaan anggaran (X1) naik sebesar 1 satuan dengan asumsi bahwa variabel bebas lainnya konstan, maka variabel Y akan mengalami kenaikan sebesar 0,191 satuan. (3) Koefisien regresi X2 sebesar 0,226 menunjukan bahwa terdapat pengaruh positif antara variabel tingkat partisipasi masyarakat (X2) dengan variabel Kualitas penyerapan anggaran $(\mathrm{Y})$ sebesar 0,226 . Hal ini menandakan bahwa jika variabel X2 naik sebesar 1 satuan dengan asumsi bahwa variabel bebas lainnya konstan, maka variabel $Y$ akan mengalami kenaikan sebesar 0,226 satuan. (4) Koefisien regresi X3 sebesar 0,238 menunjukan bahwa terdapat pengaruh positif antara variabel karakteristik kepemimpinan (X3) dengan variabel Kualitas penyerapan anggaran (Y) sebesar 0,238 . Hal ini menandakan bahwa jika variabel X3 naik sebesar 1 satuan dengan asumsi bahwa variabel bebas lainnya konstan, maka variabel Y akan mengalami kenaikan sebesar 0,238 satuan.

Uji koefesien determinasi digunakan untuk mengukur seberapa jauh kemampuan model regresi dalam menerangkan variasi variabel terikat. Pada tabel 3 berikut disajikan hasil pengujian koefisien determinasi (Adjusted R-Square).

Tabel 3. Hasil Analisis Koefisien Determinasi

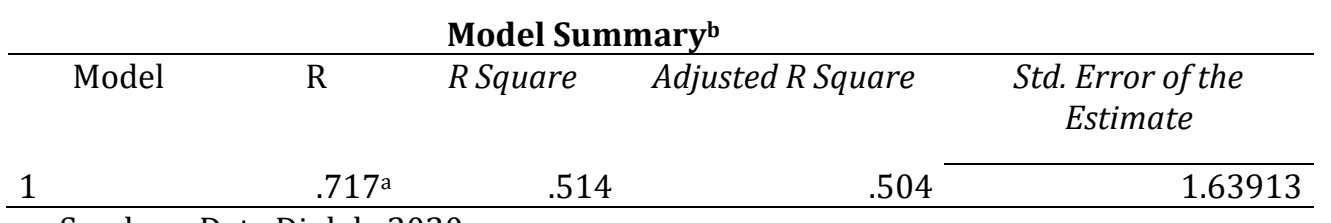

Sumber : Data Diolah, 2020

Besarnya nilai koefesien determinasi pada tabel diatas, dilihat dari nilai Adjusted R-square yaitu sebesar 0,504 atau 50,40 \% yang menunjukan bahwa variasi variabel Kualitas perencanaan anggaran, Tingkat partisipasi masyarakat, Karakteristik kepemimpinan hanya mampu menjelaskan 50,40\% variabel Kualitas Penyerapan Anggaran. Sisanya sebesar 49,60\% dipengaruhi oleh faktor lain di luar penelitian.

Uji $\mathrm{F}$ yaitu bertujuan untuk menguji pengaruh antara variabel independen terhadap variabel dependen. Berdasarkan hasil Uji F, diperoleh Nilai $F=51,464$ dengan nilai signifikan sebesar $0,000<$ 0,005 . Nilai $\mathrm{F}$ tabel diperoleh dengan derajat kebebasan $\mathrm{N}-\mathrm{k}=150-4=146$ dan $\mathrm{k}-1=4-1=3$ yaitu nilai $\mathrm{F}$ tabel adalah 2,67 sehingga $\mathrm{F}$ hitung $>\mathrm{F}$ tabel $(51,464>2,67)$ sehingga $\mathrm{H}_{1}$ diterima. Maka dapat disimpulkan bahwa model penelitian yang digunakan dianggap layak uji dan ke tiga variabel bebas mampu menjelaskan Kualitas Penyerapan Anggaran Dana Desa.

Pengujian hipotesis dengan uji $\mathrm{T}$, bertujuan untuk menguji pengaruh masing-masing variabel independen terhadap variabel dependen, dengan asumsi bahwa variabel lain dianggap konstan. Dalam penelitian ini menggunakan 150 sampel sehingga didapat Untuk mencari $t$ tabel dengan $\mathrm{df}=\mathrm{N}-\mathrm{k}$ taraf nyata $5 \%$ bisa dengan melihat tabel statistik. Berdasarkan hasil uji T tersebut, dapat dijelaskan sebagai berikut :

X1 diperoleh Thitung $>T_{\text {tabel }}(3,077>1,997)$, $(X 2)$ diperoleh $T$ hitung $>$ T tabel $(5,650>1,997)$, $(X 3)$ diperoleh T hitung $>\mathrm{T}$ tabel $(6,215>1,997)$, artinya $\mathrm{H}_{0}$ ditolak dan $\mathrm{H}_{1}, \mathrm{H}_{2}$, dan $\mathrm{H}_{3}$ diterima. Hal ini berarti kualitas perencanaan anggaran, tingkat pasrtisipasi masyarakat dan karakteristik kepemimpinan berpengaruh positif dan signifikan terhadap kualitas penyerapan anggaran.

\section{Pengaruh Kualitas Perencanaan Anggaran Terhadap Kualitas Penyerapan Anggaran Dana Desa}

Berdasarkan hasil uji statistik deskriptif, dapat dilihat bahwa variabel kualitas perencanaan anggaran $\left(\mathrm{X}_{1}\right)$ mempunyai skor minimum 14 , skor maksimum 25, skor rata-rata 20,98 dengan standar deviasi 2,375. Hal ini menunjukkan bahwa terjadi perbedaan nilai kualitas perencanaan anggaran terhadap nilai rata-rata sebesar 2,375. Sementara itu, variabel kualitas penyerapan anggaran (Y) mempunyai skor minimum 10 , skor maksimum 20, skor rata-rata 15,88 dengan standar deviasi 2,327. Hal ini menunjukkan bahwa terjadi perbedaan nilai variabel kualitas penyerapan anggaran terhadap nilai rata-rata sebesar 2,327.

Hasil uji regresi linear berganda menunjukan bahwa koefisien regresi variabel kualitas perencanaan anggaran sebesar 0,191 yang berarti bahwa apabila terdapat penambahan nilai kualitas perencanaan anggaran sebesar 1 satuan, maka kualitas penyerapan anggaran meningkat sebesar 0,191. Hasil tersebut menunjukan bahwa variabel kualitas perencanaan anggaran berpengaruh positif terhadap kualitas penyerapan anggaran. 
Berdasarkan hasil uji T secara parsial menunjukan nilai signifikansi variabel kualitas perencanaan anggaran diperoleh hasil thitung lebih besar dari t tabel $(3,077>1,997)$ dengan signifikansi 0,002. Hal ini menunjukan bahwa variabel kualitas perencanaan anggaran $\left(\mathrm{X}_{1}\right)$ berpengaruh secara signifikan terhadap kualitas penyerapan anggaran. Maka hipotesis pertama $\left(\mathrm{H}_{1}\right)$ dapat diterima yaitu kualitas perencanaan anggaran berpengaruh positif terhadap kualitas penyerapan anggaran. Maknanya, dengan adanya kualitas perencanaan anggaran perangkat desa dapat bekerja sesuai dengan rancangan anggaran yang ada sehingga menghasilkan kualitas penyerapan anggaran yang baik.

Secara empiris hasil penelitian ini didukung oleh hasil penelitian yang dilakukan oleh (Widianingrum et al., 2017) dan (Iqbal, 2018) yang menyatakan bahwa perencanaan angggaran berpengaruh terhadap penyerapan anggaran. Hasil yang sama ditunjukan oleh penelitian yang dilakukan oleh Setyawan (2016) yang menyatakan bahwa perencanaan anggaran merupakan faktor yang dominan dalam keterlambatan penyerapan anggaran belanja. Sejalan dengan penelitian (Ramadhani, 2019), menyatakan bahwa perencanaan anggaran berpengaruh positif signifikan terhadap penyerapan anggaran belanja OPD Provinsi Sumatera Barat.

\section{Pengaruh Tingkat Partisipasi Masyarakat Terhadap Penyerapan Anggaran Dana Desa}

Berdasarkan hasil uji statistik deskriptif, dapat dilihat bahwa variabel tingkat partisipasi masyarakat $\left(\mathrm{X}_{1}\right)$ mempunyai skor minimum 15, skor maksimum 30, skor rata-rata 24,64 dengan standar deviasi 3,917. Hal ini menunjukkan bahwa terjadi perbedaan nilai tingkat partisipasi masyarakat terhadap nilai rata-rata sebesar 3,917. Sementara itu, variabel kualitas penyerapan anggaran (Y) mempunyai skor minimum 10, skor maksimum 20, skor rata-rata 15,88 dengan standar deviasi 2,327. Hal ini menunjukkan bahwa terjadi perbedaan nilai variabel kualitas penyerapan anggaran terhadap nilai rata-rata sebesar 2,327.

Hasil uji regresi linear berganda menghasilkan nilai koefisien regresi variabel tingkat partisipasi masyarakat sebesar 0,226 yang berarti bahwa jika terdapat penambahan nilai tingkat partsipasi masyarakat sebesar 1 satuan, maka kualitas penyerapan anggaran meningkat sebesar 0,226. Hasil ini menunjukan bahwa tingkat partisipasi masyarakat berpengaruh positif terhadap kualitas penyerapan anggaran. Maknanya, semakin baik tingkat partisipasi masyarakat maka semakin baik kualitas penyerapan anggaran.

Hasil uji T secara parsial memperoleh hasil bahwa nilai signifikansi variabel tingkat partisipasi masyarakat menunjukan hasil $\mathrm{t}$ hitung $>\mathrm{t}$ tabel yaitu $(5,650>1,997)$ dengan signifikansi 0,000 . Hal ini menunjukan bahwa variabel tingkat partisipasi masyarakat $\left(\mathrm{X}_{2}\right)$ berpengaruh secara signifikan terhadap kualitas penyerapan anggaran. Dengan demikian hipotesis kedua $\left(\mathrm{H}_{2}\right)$ diterima, yaitu tingkat partisipasi masyarakat berpengaruh positif terhadap kualitas penyerapan anggaran.

Hasil penelitian ini didukung oleh penelitian yang dilakukan oleh Wiguna (2017) yang menyatakan bahwa partisipasi penyusunan anggaran berpengaruh signifikan terhadap kinerja pemerintah. Sejalan dengan hasil penelitian Saputra (2018), yang menyatakan bahwa penganggaran partsisipatif berpengaruh terhadap slack anggaran pada SKPK di Pemerintah Aceh. Hal senada juga dinyatakan oleh (Julianto \& Dewi, 2019) dan (Umaira \& Adnan, 2019) bahwa partisipasi masyarakat bepengaruh scara positif signifikan terhadap pengelolaan dana desa.

\section{Pengaruh Karakterintik Kepemimpinan Terhadap Kualitas Penyerapan Anggaran}

Berdasarkan hasil uji statistik deskriptif, dapat dilihat bahwa variabel karakteristik kepemimpinan $\left(\mathrm{X}_{1}\right)$ mempunyai skor minimum 26 , skor maksimum 45 , skor rata-rata 36,42 dengan standar deviasi 3,753. Hal ini menunjukkan bahwa terjadi perbedaan nilai tingkat partisipasi masyarakat terhadap nilai rata-rata sebesar 3,753. Sementara itu, variabel kualitas penyerapan anggaran (Y) mempunyai skor minimum 10, skor maksimum 20, skor rata-rata 15,88 dengan standar deviasi 2,327. Hal ini menunjukkan bahwa terjadi perbedaan nilai variabel kualitas penyerapan anggaran terhadap nilai rata-rata sebesar 2,327 .

Hasil uji regresi linear berganda menghasilkan nilai koefisien regresi variabel tingkat partisipasi masyarakat sebesar 0,238 yang berarti bahwa jika terdapat penambahan nilai karakteristik kepemimpinan sebesar 1 satuan, maka kualitas penyerapan anggaran meningkat sebesar 0,238. Hasil ini menunjukan bahwa karakteristik kepemimpinan berpengaruh positif terhadap kualitas penyerapan anggaran.

Hasil uji T secara parsial memperoleh hasil bahwa nilai signifikansi variabel karakteristik kepemimpinan menunjukan hasil t hitung $>\mathrm{t}$ tabel yaitu $(6,215>1,997)$ dengan signifikansi 0,000. Hal ini menunjukan bahwa variabel karakteristik kepemimpinan $\left(\mathrm{X}_{3}\right)$ berpengaruh secara signifikan terhadap kualitas penyerapan anggaran. Dengan demikian hipotesis kedua $\left(\mathrm{H}_{3}\right)$ diterima, yaitu karakteristik 
kepemimpinan berpengaruh positif terhadap kualitas penyerapan anggaran. Maknanya, semakin baik karakteristik kepemimpinan, semakin baik kualitas penyerapan anggaran.

Hasil penelitian ini didukung oleh penelitan yang dilakukan oleh (Dewi \& Gayatri, 2019) dan (Pramayoga \& Ramantha, 2019), yang menyimpulkan bahwa kepemimpinan berpengaruh positif terhadap akuntabilitas pengelolaan dana desa. Sejalan dengan penelitian yang dilakukan (Naelavika, 2018), bahwa kepemimpinan kepala desa memiliki pengaruh signifikan terhadap akuntabilitas pengelolaan keuangan desa.

\section{Simpulan dan Saran}

Berdasarkan hasil penelitian yang dijelaskan diatas, ditarik kesimpulan sebagai berikut : (1) Kualitas Perencanaan anggaran berpengaruh positif terhadap Kualitas Penyerapan Anggaran. Hal ini berarti semakin baik kualitas perencanaan anggaran maka kualitas penyerapan anggaran semakin baik pula. (2) Tingkat Partisipasi Masyarakat berpengaruh positif terhadap Kualitas Penyerapan Anggaran. Hal ini menunjukan bahwa semakin baik tingkat partisipasi masyarakat maka kualitas penyerapan anggaran semakin baik pula. (3) Karakteristik Kepemimpinan berpengaruh positif terhadap Kualitas Penyerapan Anggaran. Hal ini menunjukan bahwa semakin baik karakteristik kepemimpinan maka kualitas penyerapan anggaran semakin baik pula.

Adapun saran-saran yang dapat diberikan sebagai berikut : (1) Bagi Pemerintah Desa, Dengan adanya penelitian ini diharapkan dapat menambah wawasan, dapat dijadikan bahan referensi dan acuan dalam meningkatkan kualitas perencanaan anggaran, partisipasi masyarakat dan karakteristik kepemimpinan agar mampu mencapai kualitas penyerapan anggaran dana desa yang lebih baik. Dalam pengelolaan dana desa harus berdasarkan pasrtisipasi masyarakat baik dari tahap perencan aan anggaran, pelaksanaan anggaran dan evaluasi kegiatan karena peruntukan dana desa sendiri yaitu di prioritaskan untuk pembangunan desa dan pemberdayaan masyarakat desa. Segala bentuk informasi keuangan harus transparan agar tidak terjadi salah persepsi antara masyarakat dan pemerintah desa. Hal tersebut dapat dilakukan dengan memasang Baliho mengenai rincian Dana desa dan memasang papan pengumuman tentang segala bentuk pembangunan yang sedang berjalan didesa beserta rincian biayanya. (2) Bagi Peneliti Selanjutnya, Penelitian ini masi terbatas pada kualitas perencanaan anggaran, partisipasi masyarakat dan karakteristik kepemimpinan untuk penelitian selanjutnya dapat ditambah lagi dengan variabel bebas yang lain, yang diprediksi mempengaruhi kualitas penyerapan anggaran, agar nilai koefisien determinasi dalam penelitian ini meningkat misalnya seperti peran pendamping desa, regulasi, politik anggaran dan sistem anggaran berbasis kinerja karena pada penelitian terdahulu variabel tersebut diyakini mempengaruhi kualitas penyerapan anggaran.

\section{Daftar Rujukan}

Anfujatin. (2016). Analisis Faktor-faktor yang Menyebabkan Rendahnya Penyerapan Anggaran Belanja Pada SKPD Kabupaten Tuban. Jurnal Administrasi Publik.

Bastian, I. (2015). Akuntansi untuk Kecamatan dan Desa.

Dewi, N. K. A. J. P., \& Gayatri. (2019). Faktor-Faktor Yang Berpengaruh Pada Akuntabilitas Pengelolaan Dana Desa. Udayana, E-Jurnal Akuntansi Universitas, 26, 1269-1298.

Gilardi, F. (2001). Principal-agent models go to Europe: Independent regulatory agencies as ultimate step of delegation.

Iqbal, M. (2018). Pengaruh Perencanaan Anggaran dan Kompetensi Sumber Daya Manusia terhadap Penyerapan Anggaran dengan Komitmen Organisasi sebagai Pemoderasi. Universitas Hasanuddin.

Julianto, I. P., \& Dewi, G. A. K. R. S. (2019). Pengaruh Partisipasi Masyarakat, Penggunaan Sistem Keuangan Desa, Kompetensi Pendamping Desa Serta Komitmen Pemerintah Daerah Terhadap Keberhasilan Pengelolaan Dana Desa. Jurnal Ilmiah Akuntansi, 4(1), 24-42. https://doi.org/10.23887/jia.v4i1.17242

Kartono, \& Kartini. (2014). Pemimpin dan Kepemimpinan. Jakarta: Rajawali.

Naelavika. (2018). Pengaruh Kepemimpinan Kepala Desa Terhadap Akuntabilitas Pengelolaan Keuangan desa di Kecamatan Kangayan.

Pramayoga, I. B., \& Ramantha, I. W. (2019). Pengaruh Kejelasan Sasaran Anggaran, Kompetensi Aparatur Desa, dan Kepemimpinan Pada Akuntabilitas Pengelolaan Dana Desa. E-Jurnal Akuntansi, Vol. 30 No, 226-237.

Ramadhani, R. (2019). PENGARUH REGULASI, POLITIK ANGGARAN, PERENCANAAN ANGGARAN, SUMBER 
DAYA MANUSIA DAN PENGADAAN BARANG/ JASA TERHADAP PENYERAPAN ANGGARAN BELANJA PADA OPD PROVINSI SUMATERA BARAT. Duke Law Journal, 1(1), 1-13. https://doi.org/10.1017/CB09781107415324.004

Rifai, A., Inapty, B. A., \& Pancawati M., R. S. (2016). Analisis Faktor-Faktor yang Memengaruhi Keterlambatan Daya Serap Anggaran (Studi Empiris Pada SKPD Pemprov NTB). Jurnal Ilmiah Akuntansi Dan Bisnis, v. 11, n. https://doi.org/https://doi.org/10.24843/JIAB.2016.v11.i01.p01

Smith, R. W., \& Bertozzi., M. (1998). Principals and agents: An explanatory model of public budgeting. Journal of Public Budgeting, Accounting and Financial Management, 325-353.

Strom, K. (2000). Delegation and accountability in parliamentary democracies. European Journal of Political Research 37, 261-289.

Sugiyono. (2008). Metode Penelitian Bisnis.

Suwarni, D. E. (2018). Faktor-Faktor Yang Mempengaruhi Keterlambatan Penyerapan Anggaran Pendapatan dan Belanja Daerah (APBD) di Kota Surabaya (Studi pada SKPD Dinas PU Bina Marga dan Pemantusan.

Umaira, S., \& Adnan, A. (2019). Pengaruh Partisipasi Masyarakat, Kompetensi Sumber Daya Manusia, Dan Pengawasan Terhadap Akuntabilitas Pengelolaan Dana Desa (Studi Kasus Pada Kabupaten Aceh Barat Daya). Jurnal Ilmiah Mahasiswa Ekonomi Akuntansi, 4(3), 471-481. https://doi.org/10.24815/jimeka.v4i3.12580

Widianingrum, D., Kustono, A. S., \& Suryaningsih, I. B. (2017). FAKTOR-FAKTOR YANG MEMENGARUHI PENYERAPAN ANGGARAN SATUAN KERJA PERANGKAT DAERAH DI PEMERINTAH KABUPATEN SITUBONDO. Jurnal Bisnis Dan Manajemen, Vol 11 No. https://doi.org/https://doi.org/10.19184/bisma.v11i2.6314

Zarinah, M., Darwanis, \& Abdullah, S. (2016). PENGARUH PERENCANAAN ANGGARAN DAN KUALIAS SUMBER DAYA MANUSIA TERHADAP TINGKAT PENYERAPAN ANGGARAN SATUAN KERJA PERANGKAT DAERAH DI KABUPATEN ACEH UTARA. Jurnal Administrasi Akuntansi : Program Pascasarjana Unsyiah, Vol. 5 No. 